\title{
MATERI KHOTBAH DAN KOMUNIKASI MIMBAR
}

\section{Sunarto}

\section{ABSTRAK}

Kehausan jemaat dalam mendengarkan berita khotbah kadang dilumpuhkan oleh materi khotbah dan komunikasi mimbar yang lemah. Dua dimensi khotbah yang harus diperkuat secara seimbang adalah materi khotbah yang alkitabiah dan komunikasi mimbar yang baik. Menimbulkan minat pada khotbah bukan saja menuntut pada diri pendengar, tetapi harus ada kemauan yang kuat bagi pengkhotbah untuk menyiapkan materi khotbah yang tepat dan membangun komunikasi mimbar yang baik. Apabila satu diantaranya terbaikan maka tujuan mulia dari pelayanan mimbar menjadi menjadi tidak maksimal.

\section{PENDAHULUAN}

Berkhotbah adalah bagian penting yang harus dilaksanakan bagi seorang pendeta, penatua atau setiap orang percaya yang terpanggil dalam pelayanan ini. Seperti apa yang dikatakan oleh John Stott dan Greg Scharf bahwa "berkhotbah merupakan bagian yang sangat penting dalam kekristenan berdasarkan pada kebenaran bahwa Tuhan menggunakan firman-Nya untuk menyatakan diri-Nya kepada manusia."1 Namun ketika khotbah itu disampaikan, ada berbagai hambatan yang harus dihadapi. Bukan hanya dalam diri pengkhotbah, tetapi dalam diri pendengar juga bisa menghadapi berbagai hambatan.

Ketika khotbah disampaikan kepada para pendengar, pengkhotbah merasa yakin bahwa mereka sudah mengerti, padahal mereka bingung apa yang sudah didengarnya. Sebagian besar pendengar tidak mengerti karena

1John Stott \& Greg Scharf, Tantangan dalam Berkhotbah (Jakarta: Yayasan Komunikasi Bina Kasih, 2013), 19. 
bahasa yang digunakan sulit ditangkap, ditambah dengan penjelasan yang berbelit-belit. Paradigma berpikir pendengar bisa juga memberi pengaruh, tidak ada kebenaran yang objektif, segala sesuatu bersifat subjektif. "Kesimpulan tentang kebenaran suatu hal tergantung pada individu-individu yang pengalaman hidupnya sesuai dengan hal itu. Jika kebenaran dikatakan tidak sesuai dengan pengalaman individu atau umat, pasti akan ditolak."2

Ilmu berkhotbah adalah sebuah disiplin ilmu berbicara dihadapan orang banyak supaya pokok yang disampaikan dapat disajikan dengan cara yang jelas dan dapat diterima oleh pendengar. Pengertian tersebut mengandung dua aspek penting, yaitu materi khotbah yang tepat dan penyampaian pesan yang baik. Terpenuhinya dua aspek khotbah tersebut akan mempengaruhi apakah sebuah pesan dalam suatu khotbah dapat dimengerti oleh para pendengar atau tidak.

Ada dua masalah yang kadang bisa terjadi dalam pelayanan berkhotbah. Pertama, materi khotbahnya sudah berkualitas karena sudah dipersiapkan dengan baik, tetapi ketika disampaikan kepada para pendengar materi khotbahnya tidak dapat dimengerti karena masalah komuniasi yang jelek (lemah). Kedua, materi khotbahnya kurang berkualitas, tetapi karena disampaikan dengan sangat baik, sehingga materi yang kurang berbobot itu menjadi tertutupi.

Khotbah yang efektif seharusya memadukan dua aspek penting, yaitu materi khotbah yang baik dan komunikasi mimbar yang baik pula. Tugas seorang pengkhotbah memperlengkapi diri dengan dua aspek penting tersebut. Menyiapkan materi yang tepat dan menyampaikan khotbah yang alkitabiah memerlukan perlengkapan dasar yang harus dipenuhi bagi seorang pengkhotbah. Di manakah seorang pengkhotbah bisa mendapatkah materi khotbah yang baik? Apakah tujuannya seorang pengkhotbah menyiapkan materi khotbah? Haruskah materi khotbah disusun dalam format tertentu? Komunikasi mimbar yang bagaimanakah supaya khotbah bisa disampaikan dengan cara efektif? Faktor lain, apakah yang bisa mendukung dalam komunikasi mimbar?

Jawaban terhadap berbagai pertanyaan tersebut akan memberi gambaran yang utuh bagaimana seorang pengkhotbah bisa memadukan

2Ibid, 21. 
antara materi khotbah yang baik dan menerapkan komunikasi yang baik pula. Terpenuhinya dua aspek tersebut diharapkan sebuah khotbah akan menjadi makanan rohani yang bisa membantu pertumbuhan rohani jemaat.

\section{MATERI KHOTBAH}

\section{Sumber Materi Khotbah}

Ketika seorang pengkhotbah mempersiapkan diri secara pribadi, apakah yang harus dipersiapkan? Persiapan yang dimaksud tentunya adalah materi khotbah. Dari manakah sumber materi khotbah? Apakah dari berita televisi? Apakah dari surat kabar cetak atau sumber online? Atau dari perkataan tokoh-tokoh ilmuwan, para filsuf atau dari perkataan orang-orang yang terkenal? Kalau materi itu bersumber dari televisi, perkataan para ilmuwan, para filsuf atau orang yang terkenal, bukankah para pendengar tidak perlu hadir dalam sebuah kebaktian? Mereka bisa membaca dan mendengarkan di rumah masing-masing atau di mana pun mereka berada

Bukan rahasia lagi kalau para pengkhotbah banyak mengutip apa yang diberitakan oleh telivisi, dari surat kabar, perkataan dari para ilmuwan, para filsuf dan perkataaan dari orang-orang yang terkenal! Apakah itu yang disebut dengan memberitakan firman Tuhan? Bahkan ada seorang pengkotbah setelah membaca Alkitab lalu ia membicarakan hal-hal yg terjadi di masyarakat, baik dari televisi atau pun dari berbagai buku yang dimiliki. Sampai khotbah selesai sang pengkhotbah tidak membahas apa yang telah dibaca dari Alkitab. Apakah materi khotbah yang demikian disebut dengan memberitakan firman Tuhan.

Berikut sumber sekunder dan primer yang harus dipertimbangkan oleh seorang pengkhotbah ketika sedang mempersiapkan materi khotbah:

\section{Wahyu Umum (Alam Semesta, Hati Nurani dan Sejarah)}

Wahyu umum atau penyataan umum adalah Allah memperkenalkan diri-Nya kepada manusia di semua tempat dan waktu melalui isi dunia sekitar kita, dalam hal ini termasuk manusia. Penyataan ini disebut umum, 
karena diperuntukkan bagi manusia pada umumnya, tanpa kecuali. Alkitab sendiri mengatakan bahwa pengetahuan tentang Allah dapat dikenal melalui tatanan alam raya. "Langit menceritakan kemuliaan Allah" dan "cakrawala memberitakan pekerjaan tangan-Nya" (Mazmur 19:2). Allah menyatakan diri melalui pelbagai kebajikan, menurunkan hujan, memberikan musimmusim subur, makan dan lain-lain (Kisah 14:17). Ada penyataan diri Allah melalui kekuatan dan keilahian-Nya melalui karya cipta-Nya (Roma 1:1920).

Tempat kedua dari wahyu umum ialah puncak ciptaan Allah di atas bumi, yaitu manusia. Manusia diciptakan dengan memiliki kemampuan moral yang bersumber dari hati nurani. Kemampuan hati nurani mendorong manusia untuk mengambil keputusan-keputusan moral, yaitu keputusan mana yang dianggap benar dan mana yang salah. ${ }^{3}$ Paulus membicarakan mengenai hukum Allah yang ditulis dihati kita (Roma 2:12-16). Di manamana kebudayaan menyaksikan semacam kegiatan-kegiatan agamawi. Ini merupakan bukti yang tidak dapat disangkal bahwa ada sifat agamawi yang secara alamiah ada di dalam diri manusia. Dengan demikian umat manusia pada dasarnya merupakan makhluk religius.

Tempat ketiga dari wahyu umum ialah sejarah. Untuk mengetahui karya Allah dalam sejarah itu perlu merujuk kepada catatan-catatan sejarah pula. Sebuah contoh yang sering kali dikutip penyataan Allah dalam sejarah ialah pemeliharaan bangsa Israel. Bangsa yang kecil ini bisa bertahan hidup selama berabad-abad di tengah-tengah lingkungan yang tergolong bermusuhan, bahkan sering kali menghadapi perlawanan yang hebat. ${ }^{4}$

Keberadaan wahyu umum juga bisa digunakan sebagai sumber khotbah, tetapi manusia tidak bisa menemukan Allah secara alami dan alamiah; artinya alam tidak bisa menjadi sarana lengkap bagi manusia untuk menemukan Allah. Manusia yang telah jatuh ke dalam dosa, menjadikan penyataan umum tidak lagi memadai untuk menuntun manusia dalam pengenalan akan Allah. Manusia supaya dapat mengenal Allahnya membutuhkan penyataan penyatan lain, yang secara teologis disebut sebagai

3Ibid, 195.

${ }^{4}$ Millard J. Erickson, Teologi Kristen, Volume Satu (Malang: Gandum Mas, 1999), 195. 
penyataan khusus, Allah lah sumber penyataan khusus dan Kristuslah pusat penyataan khusus.

\section{Wahyu Khusus (Alkitab)}

Penyataan khusus artinya cara Allah mengkomunikasikan atau memperkenalkan diri-Nya melalui orang-orang tertentu dan pada waktu tertentu yang disampaikan melalui wahyu yang telah ditulis di dalam Alkitab. Karena manusia telah jatuh ke dalam dosa, maka penyataan umum tidak lagi memadai untuk menuntun manusia dalam pengenalan akan Allah. Manusia supaya dapat mengenal Allahnya membutuhkan penyataan penyatan lain, yang secara teologis disebut sebagai penyataan khusus, Allah lah sumber penyataan khusus.

Alkitab sebagai wahyu khusus Allah merupakan sumber primer pertama dan yang paling utama dalam berkhotbah. Jika seorang pengkhotbah mau berkhotbah, maka tidak dapat melepaskan dari teks Alkitab. Alkitab adalah firman Allah yang diwahyukan untuk menyatakan kebenaran kepada manusia. Alkitab merupakan standar, pegangan, dan dasar dalam membangun sebuah teologi karena melalui Alkitab, kebenaran Allah dinyatakan kepada manusia. Alkitab merupakan dasar atau sumber berkhotbah karena kita memiliki keyakinan bahwa Alkitab merupakan pernyataan Wahyu Allah untuk kehidupan manusia (2 Tim 3:16).

Alkitab merupakan sarana yang paling menyeluruh dari semua saluran penyataan khusus dari Allah. Alkitab isinya mencakup banyak segi dari saluran-saluran lain yang dipakai oleh Allah, semua dalam rangka memperkenalkan diri-Nya kepada umat-Nya. Agar penyataan ilahi (pembukaan diri, penyataan kehendak oleh semua generasi, maka, Allah memerintahkan agar semua penyatan tersebut dituliskan. Inilah yang Allah instruksikan kepada Musa (2 Taw. 9:29). Tujuan utama dari penulisan Alkitab adalah agar jemaat di segala tempat dan zaman bisa mengenali Allah, beroleh dasar dan mempunyai pegangan kepercayaan kepada Allah yang telah menyatakan diri. Alkitab adalah buah karya-Nya Allah. Allah adalah primarus, pembuat yang pertama atau utama.

Alkitab sebagai sumber utama khotbah seharusnya tidak menjadikan seorang pengkhotbah kebingungan materi khotbah karena di dalamnya terkandung kekayaan yang luar biasa. Alkitab merupakan sebuah sumber 
yang melimpah dengan berbagai bentuk sastra, misalnya: puisi, hukum, perumpamaan, dan cerita. Sumber yang beraneka ragam memberikan pelajaran yang berarti bagaimana seorang pengkhotbah bisa menjadi seorang komunikator yang ulung. Allahlah Sang komunikator ulung jikalau setiap pengkhotbah mau membaca dan mempelajari Alkitab. ${ }^{5}$

\section{Tujuan Materi Khotbah}

Apakah tujuannya ketika seorang pengkhotbah mempersiapkan materi khotbah? Apakah agenda pribadi sendiri yang akan disampaikan? Apabila itu yang disampaikan adalah agenda pribadi dari seorang manusia, patut dipertanyakan apakah betul yang bersangkutan seorang abdi Tuhan! Bertolak dari berita Alkitab seorang nabi yang benar hanya memberitakan apa yang disampaikan Allah kepada dirinya.

Jauh sebelum khotbah disampaikan dimimbar-mimbar gereja, Allah sudah sejak lama memanggil para nabi untuk menyampaikan warta kebenaran-Nya. Para nabi dipanggil untuk menjadi corong Allah, karena hakikat dari pemanggilan pelayanan nabi adalah menjadi penyambung lidah Allah. Nabi-nabi berkata-kata bukan atas kesenangannya pribadi, tetapi mereka menyampaikan apa menjadi kehendak Allah bagi umat-Nya. Demikian dikatakan dalam Keluaran 5:1 "Kemudian Musa dan Harun pergi menghadap Firaun, lalu berkata kepadanya: "Beginilah firman TUHAN, Allah Israel: Biarkanlah umat-Ku pergi untuk mengadakan perayaan bagiKu di padang gurun."

Pada era kerajaan Israel kehendak Allah untuk menyampaikan khotbah kepada umat-Nya juga diteruskan dengan memanggil para nabi pada zaman itu. Ketika Saul diangkat untuk menjadi raja Israel dan memimpin bangsa ini, Allah memakai Samuel untuk mendampingi umat-Nya. Samuel pula yang dipakai oleh Allah untuk menyatakan kehendak-Nya supaya bangsa Israel hidup berkenan pada Allah. Ketika Saul sang pemimpin mulai menyimpang dari kehendak Allah, Allah memakai Samuel untuk menegor Saul, bahwa apa yang dilakukan telah menyimpang dari kehendak Allah.

Allah memilih para hamba-Nya untuk menyatakan kehendak-Nya, misalnya melalui Ezra (seorang ahli kitab) untuk menyatakan kehendak-Nya

5Jeffrey D. Arthurs, Preaching With V ariety (Malang: Literatur SAAT, 2012), 24. 
kepada umat yang sudah kembali dari tanah pembuangan. Ia memilih Ezra untuk berdiri lebih tinggi dari orang banyak dan membuka Firman (Neh. 8:5). Ia meletakkan firman di dalam mulut para nabi (Yer. 1:9). ${ }^{6}$ Maka jelaslah seorang pemberita firman berkhotbah menyampaikan warta kebenaran dari Allah. Tidak ada agenda pribadi oleh karena keinginan tertentu dari seorang pengkhotbah.

\section{Desain (Struktur) Materi Khotbah}

Sekalipun tidak ada satu bentuk khotbah yang baku, namun bukan berarti sebuah khotbah disampaikan tanpa format atau bentuk yang tidak jelas. Materi khotbah yang sudah dipersiapkan sebaiknya menggunakan desain yang baik. Desain materi khotbah berkaitan dengan cara sesuatu disusun atau dibangun. Ibarat seperti membangun rumah memerlukan pondasi, tembok, pintu, jendela sampai dengan atapnya. Tanpa desain khotbah yang logis dan jelas, suatu khotbah tidak akan berpengaruh dan berkuatan sebagaimana mestinya. Bahkan tidak menutupi kemungkinan tanpa struktur khotbah yang baik dapat menimbulkan kebingungan pendengar. Untuk menghindari kebingungan tersebut, pengkhotbah harus memahami dan memerlukan desain khotbah yang baik. ${ }^{7}$

Ada berbagai bentuk khotbah yang dapat dipilih oleh pengkhotbah, apapun bentuknya suatu khotbah memerlukan desain atau struktur. Bentuk yang dipilih memerlukan persiapan, perencanaan dan penyajian yang baik. Khotbah tanpa desain ibarat seperti rumah yang dibangun dengan tidak memperhitungkan bagian-bagian dari rumah menurut tata letak yang tepat. Akibatnya rumah tersebut tidak memiliki bentuk yang baik karena dibangun tanpa perencanaan dan yang penting bangunan rumah bisa berdiri. Rumah yang baik bukan asal berdiri, tetapi juga harus memperhatikan nilai-nilai estetikanya.

Mengapa desain materi khotbah itu penting? Kitab-kitab yang ada di Alkitab ditulis dalam konteks budaya manusia yang sedang berkembang pada zamannya. Dari segi kesusasteraan teks-teks kitab Suci ditulis juga

${ }^{6}$ Kenton C. Anderson, Choosing to Preach (Malang: Gandum Mas, 2010), 29.

7Jerry Vines dan Jim Shaddix, Homiletika, Kuasa dalam Berkhotbab (Malang: Gandum Mas, 2009), 203-204. 
menggunakan bentuk sastra yang berkembang pada zamannya. Maka dilihat dari muatan isi pesannya setiap teks menggunakan susunan, misalnya ada bagian pendahuluan, pesan utama dan bagian penutup. Tugas seorang pengkhotbah adalah bagaimana menemukan pesan utama dari sebuah teks dan maknanya bagi pendengar di era sekarang.

Maka khotbah yang benar adalah khotbah yang alkitabiah dan di desain dengan menggunakan pola yang baik. Khotbah alkitabiah adalah khotbah yang menempatkan Alkitab pada pusatnya, khotbah yang menyingkapkan kekuatan dan kekuasaan Alkitab. Sekalipun seorang pengkhotbah itu mengkhotbahkan tentang topik atau tema tertentu. Tugas seorang pengkhotbah ketika ia menjelaskan tema tersebut, materi khotbahnya harus di desain dengan baik. Sebab materi khotbah yang disusun dengan menggunakan desain yang baik akan menolong para pendengar untuk memahaminya.

\section{KOMUNIKASI MIMBAR}

\section{Pengertian Komunikasi Mimbar}

Para pakar mendefinisikan komunikasi secara beragam, ada yang mendefinisikan secara sempit ada juga yang mendefinisikan secara luas. Bukan hanya manusia yang bisa berkomunikasi, bahkan hewan juga melakukan komunikasi. Artikel ini tidak membahas komunikasi hewan, tetapi komunikasi antara manusia atau yang disebut buman communication (komunikasi manusia).

Apakah komunikasi manusia itu? Ada beberapa yang mendefinisikan komunikasi manusia: Gerald R mendefinisikan "komunikasi terjadi ketika suatu sumber menyampaikan suatu pesan kepada penerima dengan niat yang didasari untuk mempengaruhi perilaku penerima". ${ }^{8}$ Menurut Everett M. Rogers: "komunikasi adalah proses di mana suatu ide dialihkan dari sumber kepada suatu penerima atau lebih, dengan maksud untuk mengubah

${ }^{8}$ Deddy Mulyana, Ilmu Komunikasi, Suatu Pengantar (Bandung: PT Remaja Rosdakarya, 2014), 68. 
tingkah laku mereka." Sedangkan menurut Donal Byker dan Loren J. Anderson mendefinisikan "komunikasi (manusia) adalah berbagi informasi antara dua orang atau lebih."

Pengertian atau definisi yang digunakan dalam pembahasan artikel ini dibatasi dalam konteks komunikasi mimbar yang dilakukan oleh seorang pemberita firman atau pengkhotbah. Meskipun demikian pengertian komunikasi mimbar tidak bisa dilepaskan dari prinsip-prinsip umum dalam teori komunikasi. Komunikasi adalah pengiriman dan penerimaan pesan atau berita antara dua orang atau lebih sehingga pesan yang dimaksud dapat dipahami. Komunikasi mimbar artinya seorang pengkhotbah menyampaikan pesan atau gagasan kepada para pendengar dengan cara yang efektif supaya pesan atau berita yang disampaikan bisa di mengerti dengan baik. Komunikasi mimbar merupakan bagian dari penerapan teori ilmu komunikasi.

Ada perbedaan yang besar antara komunikasi tertulis dengan komunikasi secara verbal atau lisan. Komunikasi secara tertulis memilili keuntungan bahwa penerima berita bisa membaca secara berulang-ulang, tetapi komunikasi secara lisan apabila diterima oleh pendengar ia tidak dapat mengulanginya, kecuali seorang pembicara mengulanginya. Komunikator lisan harus menggunakan kata-kata yang langsung bisa dimengerti pada saat itu diucapkan. ${ }^{10}$ Jadi komunikasi mimbar karena termasuk menggunakan komunikasi verbal atau lisan seorang komunikator harus memperhatikan prinsip-prinsip teori komunikasi ini.

\section{Memahami Konteks-Konteks Komunikasi Mimbar}

Komunikasi mimbar tidak berlangsung dalam ruang yang hampa, melainkan berada dalam konteks atau dalam situasi tertentu. Ketika seorang pengkhotbah berbicara dihadapan para pendengar ia sedang berada dalam konteks tertentu juga. Secara luas konteks yang sedang dihadapi seorang pengkhotbah harus memahami 4 konteks, yaitu aspek fisik, psikologis, sosial dan waktu. Semua aspek tersebut harus dipafahami oleh seorang

${ }^{9}$ Ibid, 69.

${ }^{10}$ Jerry Vines dan Jim Shaddix, Homiletika, Kuasa dalam Berkhotbah, 334. 
pengkhotbah, karena seorang pengkhotbah adalah seorang komunikator pesan $^{11}$

Pertama, konteks fisik berkaitan situasi alam, iklim, cuaca, tempat, bentuk ruangan, penataan tempat duduk, jumlah peserta komunikasi, alat yang tersedia untuk menyampaikan pesan. Cuaca yang panas atau udara yang sejuk turut mempengaruhi daya tahan konsentrasi dari para pendengar Berkaitan dengan tempat, misalnya apakah seorang pengkhotbah berbicara di luar ruangan atau di dalam ruangan. Masalah tempat harus menjadi pertimbangan bagaimana pola penyampaian materi itu disampaikan.

Kedua, berkaitan dengan aspek psikologis para pendengarnya siapa saja harus menjadi pemahaman bagi seorang komonikator. Psikologis dari kata psikologi adalah salah satu bidang ilmu pengetahuan dan ilmu terapan yang mempelajari mengenai perilaku, fungsi mental, dan proses mental manusia secara ilmiah. Apakah ia sedang berbicara kepada anak-anak, remaja, pemuda, orang dewasa atau kaum lansia. Pemahaman psikologi yang benar akan menolong seorang pengkhotbah untuk menyiapkan materi dan pola penyampaiannya.

Ketiga, berkaitan dengan konteks sosial. Konteks sosial perlu menjadi pengetahuan karena seorang komunikator ia sedang berada dalam konteks sosial tertentu dalam masyarakat. Setiap masyarakat mempunyai karakteristik budaya yang berbeda, adat istiadat dan norma yang berbeda dengan masyarakat lainnya. Konteks sosial juga harus dipahami supaya pengkhotbah mempunyai kepekaan berkaitan kebiasan masyarakat setempat.

Keempat berkaitan dengan konteks waktu. Begitu juga masalah waktu (pagi, siang atau malam) harus menjadi pertimbangan teknik komunikasi pesan yang akan disampaikan. Menurut Joseph A. DeVito "bagi banyak orang, pagi hari bukanlah waktu untuk berkomunikasi; bagi orang lain, pagi hari justru waktu yang ideal. Waktu dalam sejarah tidak kurang pentingnya, karena kelayakan dan dampak dari suatu pesan bergantung, sebagian, pada waktu atau saat dikomunikasikan." 12

${ }^{11}$ Deddy Mulyana, Ilmu Komunikasi, Suatu Pengantar, 82.

${ }^{12}$ Joseph A. DeVito, Komunikasi Antar Manusia (Pamulang, Tangerang Selatan: Karisma Publishing Group, Tnp. Tahun), 25 
Seorang pengkhotbah adalah seorang komunikator pesan. Seorang komunikator disamping memerlukan pemahaman konteks komunikasi, juga memerlukan pemahaman tentang bentuk-bentuk komunikasi yang harus difahami oleh seorang komunikator. Ada beberapa bentuk komunikasi yaitu: komunikasi antarpribadi, komunikasi kelompok dan komunikasi publik. ${ }^{13}$

Komunikasi antarpribadi dapat didefinisikan sebagai komunikasi yang berlangsung di antara dua orang yang mempunyai hubungan yang mantap dan jelas. Komunikasi ini lebih dikenal dengan interpersonal: komunikasi yang terjadi antar komunikator dengan komunikan secara langsung dengan cara berhadapan muka atau tidak. Komunikasi seperti ini lebih efektif karena kedua belah pihak saling melancarkan komunikasinya dan dengan feedback keduanya melaksanakan fungsi masing-masing, misalnya komunikasi antara pramuniaga dan pelanggan, antara anak dan ayah, dua orang yang sedang wawancara dan sebagainya.

Komunikasi kelompok, yakni komunikasi yang terjadi antara seseorang dan kelompok tertentu. Ada kelompok sedikit orang, ada kelompok agak banyak orang dan kelompok dengan banyak orang. Komunikasi kelompok merupakan komunikasi yang melibatkan interaksi antara kelompok dengan individu, individu dengan kelompok, kelompok dengan kelompok.

Komunikasi massa (publik) merupakan bentuk komunikasi yang menggunakan saluran (media) dalam menghubungkan komunikator dan komunikan secara massal, berjumlah banyak, bertempat tinggal yang jauh, sangat heterogen, dan menimbulkan efek tertentu. Jadi, Komunikasi massa sebagai pesan yang dikomunikasikan melalui media massa pada sejumlah besar orang. Komunikasi publik, jenis komunikasi ini menggunakan media sebagai alat atau sarana bantu, biasanya menggunakan media elektronik seperti televisi, radio, surat kabar, majalah dan lain-lain.

\section{Prinsip-Prinsip Penting Komunikasi Mimbar}

Komunikasi adalah aktivitas hidup yang setiap hari dilakukan oleh manusia. Bila pengertian komunikasi mimbar yang merupakan bagian dari

${ }^{13}$ Deddy Mulyana, Ilmu Komunikasi, Suatu Pengantar, 82. 
ilmu komunikasi, maka seorang pengkhotbah harus memperhatikan prinsipprinsip komunikasi mimbar. Berikut akan diuraikan beberapa prinsip yang harus dikuasai oleh pengkhotbah supaya pesan yang disampaikan bisa mencapai sasaran dengan tepat.

\section{Menguasai Materi}

Menguasai materi adalah prinsip pertama bagi setiap komunikator dalam bidang apapun. Seorang pengkhotbah harus menjadi seorang komunikator lisan yang baik. Tanpa penguasaan materi khotbah, maka dapat dipastikan akan mempengaruhi kelancaran pada saat berita khotbah itu disampaikan. Penguasaan materi adalah hukum mutlak bagi setiap pembicara yang ingin berbicara dalam forum apapun. Untuk dapat menguasai materi seorang pembicara harus mempersiapkan naskah atau catatan yang memadai. Gagal mempersiapkan materi sama dengan merencanakan sebuah kegagalan dalam bekerja.

Membaca naskah secara berulang-ulang barangkali salah satu tip untuk mempersiapkan diri sebelum seseorang menyampaikan khotbahnya kepada para pendengar. Ungkapan rohani bahwa Roh Kudus akan menolong setiap pengkhotbah tidak boleh menggantikannya sehingga seseorang tidak merasa perlu untuk berlatih. Ungkapan tersebut bisa juga untuk menutupi sikap malas untuk bekerja keras waktu mendapatkan jadwal untuk berkhotbah.

Pengusaan materi seorang pembicara akan tampak dari apa yang disampaikan. Apakah ia lancar dalam berbicara? Apakah ia sangat bergantung pada catatan yang ada? Apakah ia bisa menjelaskan tema dengan baik? Apakah ia bisa menggunakan waktu yang disediakan secara baik atau waktu yang tersisa cukup banyak karena sudah selesai lebih awal.

Hukum berlatih selalu lebih baik daripada tidak berlatih sebelum penampilan. "Penampilan luar biasa tidak harus sempurna. Bahkan, jarang ada penampilan luar biasa yang sempurna. Latihan mungkin tidak menciptakan kesempurnaan, tapi jika dilakukan secara benar, latihan akan selalu membuat Anda lebih baik."14 Hukum ini juga berlaku bagi seorang

${ }^{14}$ Mark Sanborn, Rahasia Jadi Bintang di Segala Bidang (Jakarta: Gramedia Pustaka Utama: 2010), 89. 
pengkotbah bahwa berlatih untuk menguasai materi akan selalu lebih baik dari pada tidak mempersiapkan diri.

\section{Jelas Bagi Pengkhotbah dan Pendengar}

Berita yang disampaikan oleh seorang pengkhotbah bukan jelas bagi seorang pengkhotbah saja, tetapi juga harus jelas bagi para pendengar. Apabila para pendengar bisa mengerti dan memahami apa yang disampaikan oleh seorang pengkhotbah, tentu bagi sang pengkhotbah pasti sudah menguasai bahannya. Sebaliknya apabila seorang pengkhotbah merasa ia sudah jelas bagi dirinya, tetapi belum tentu jelas bagi para pendengarnya.

Untuk melihat apakah materi khotbah sudah jelas bagi para pendengar sebaiknya seorang pengkhotbah meminta evaluasi atau masukan dari beberapa orang pendengar. Sebagian pengkhotbah enggan atau tidak bersedia untuk dievaluasi, sikap yang demikian sulit untuk mengetahui apakah khotbah yang disampaikan sudah dimengerti oleh pendengar atau tidak. Evaluasi khotbah penting untuk mengetahui tingkat pemahaman para pendengar terhadap khotbah yang sudah disampaikan. Evaluasi khotbah juga berguna untuk mengukur kesetiaan pada Alkitab, kejelasan penyampaian dan relevansinya materi khotbah dengan pendengar.

Berkaitan dengan khotbah yang jelas bagi pengkhotbah dan pendengar, Jonathan Lamb mengatakan demikian:

Struktur yang jelas bisa menolong sang pengkhotbah mengatur alur pemikiranpemikirannya dan menyampaikannya secara persuasif dan bisa diingat. Khotbah yang terstruktur juga menunjukkan kepada para pendengar bahwa sang pengkhotbah telah melakukan tugasnya dalam memahami isi perikop serta menyiapkan khotbahnya. Akhirnya, struktur yang jelas dan baik bisa menolong para pendengarnya untuk berkonsentrasi dan terfokus para perikop, dan kemudian bisa mengingat pokok utamanya. ${ }^{15}$

Sebuah perikop Alkitab yang sulit sekalipun ketika itu disampaikan kepada para pendengar, tugas seorang pengkhotbah adalah memperjelas apa

${ }^{15}$ Christopher J.H Wright, Memahami \& Menggunakan Alkitab (Jakarta: Yayasan Pancar Pijar Alkitab, 2009), 336. 
yang sulit. Bukan justru menjadi lebih sulit karena tidak mampu menyampaikan materi dengan cara yang baik sehingga pendengar menjadi bingung. Jadi khotbah harus disampaikan dengan jelas bagi pengkhotbah dan pendengar.

\section{Menggunakan Kata-kata yang Sederhana}

Khotbah yang baik bukan diukur oleh penggunaan kata-kata yang akademis, dengan menggunakan istilah yang teologis, atau penggunaan bahasa asing, termasuk penggunaan bahasa asli Alkitab. Penggunaan katakata yang akademis, istilah yang teologis, atau pun menggunakan bahasa asing menjadi tidak efektif dan sia-sia kalau para pendengarnya tidak memahaminya. Hakikatnya khotbah yang baik adalah khotbah yang dapat dimengerti oleh pendengar dan menggerakkan mereka untuk melakukan berita firman.

Prinsip komunikasi mimbar yang harus dikembangkan adalah pengkhotbah harus menyusun materi khotbah dengan bahasa yang sederhana mungkin. Kegiatan ibadah yang intergenernasi misalnya, ibadah bukan hanya dihadiri oleh orang-orang dewasa, tetapi juga di hadiri oleh kaum remaja dan anak-anak. Ibadah yang intergenerasi menjadi tantangan tersendiri bagi setiap pengkhotbah. Penggunaan kata-kata yang sederhana akan menjangkau mereka sehingga anak-anak pun bisa mengerti akan khotbah yang disampaikan.

Bila anak-anak kecil itu mengerti kata-kata yang digunakan oleh seorang pengkhotbah, Anda tidak perlu lagi bertanya, apalah mereka yang dewasa memahami atau tidak. Apabila ada rumput diletakkan di rak yang paling bawah, maka kelinci-kelinci akan mudah memakannya, tentunya juga semua jerapah di lingkungan tersebut. Bahasa yang sederhana lebih mudah dimengerti daripada dibuat-buat, dengan istilah teknis, teologis dan impresif. Mungkin saja kata-kata tersebut membuat beberapa orang menjadi terkesan, namun akan membinggungkan mayoritas pendengar. ${ }^{16}$

Sekalipun demikian bukan berarti diharamkan dengan menggunakan istilah-istilah yang teologis. Istilah yang ada di Alkitab dari bahasa aseli bisa digunakan sepanjang kata-kata tersebut dijelaskan dengan menggunakan 
kata atau bahasa yang sederhana sehingga para pendengar bisa mengerti. Jadi pada hakikatnya penggunaan kata-kata yang sulit yang harus dijelaskan artinya supaya para pendengar menjadi paham dan jelas.

\section{Seimbang Secara Kognitif dan Afektif}

Materi khotbah yang disampaikan hendaknya mempertimbangkan keseimbangan antara pemikiran secara rasio dan emosi. Dua kecenderungan yang kadang terjadi dalam sebuah khotbah, kadang terlalu menekankan pemikiran secara akademis sehingga materi yang disajikan dipenuhi dengan istilah yang sulit. Disisi yang lain ada seorang pengkhotbah terlalu menekankan sentuhan emosi, sehingga materi yang disajikan hanya hal-hal yang ringan saja.

Kunci dari khotbah kognitif (rasio) adalah fokus pada ide-ide yang ada pada khotbah. Penekanan dasar dalam khotbah kognitif menggunakan dalil dan argumen. Kebenaran diperoleh melalui ajaran, dan itu terdapat pada khotbah di mana kebenaran dengan jelas dan dimengerti. Khotbah kognitif disampaikan untuk memperlengkapi pendengar dengan prinsip-prinsip firman Tuhan yang tetap ada di sepanjang masa. Seperti yang dikatakan oleh Tuhan 2 Timotius 3:16 "Segala tulisan yang diilhamkan Allah memang bermanfaat untuk mengajar, untuk menyatakan kesalahan, untuk memperbaiki kelakuan dan untuk mendidik orang dalam kebenaran. ${ }^{17}$

Sementara khotbah kognitif melihat dengan jelas pada ide-ide khotbah, khotbah afektif (unsur emosi), berfokus pada kesan. Pengkhotbah menyentuh hati pendengar melalui gambaran dan penjelasan dari khotbah itu, menciptakan keinginan untuk berubah pada tingkat yang berbeda dari apa yang dikerjakan oleh logika. Jenis khotbah seperti ini barangkali cocok bagi orang yang memiliki kepekaan perasaan "perasa" daripada "pemikir". Allah telah menciptakan manusia dengan kemampuan baik untuk berpikir maupun untuk merasa. Jikalau ada sebagian orang lebih condong kepada yang satu daripada yang lain itu seharusnya bukan menjadi masalah bagi seorang pengkhotbah yang mengerti bagaimana khotbah diberitakan. ${ }^{18}$

${ }^{17}$ Kenton C. Anderson, Choosing to Preac, 110

${ }^{18} \mathrm{Ibid}, 130-131$. 
Komunikasi mimbar yang sehat seharusnya mempertimbangkan duaduanya, yaitu seimbang secara rasio dan emosi. Terkait dengan keseimbangan antara rasio dan emosi Hasan Sutanto mengatakan demikian:

Tanpa memuaskan kebutuhan rasio pendengar, sudah tentu mereka tidak percaya pada apa yang didengarnya. Khotbah yang efektif memiliki pembahasan yang rasional, argumen yang kuat, atau bukti yang mendukung. Di lain pihak, komunikasi lisan juga perlu memperhatikan unsur emosi. Emosi adalah faktor yang sangat menentukan kesuksesan komunikasi. Kebutuhan manusia dalam hal emosi perlu dipuaskan. ${ }^{19}$

Paulus juga berbicara tentang keseimbangan antara pikiran dan perasaan (emosi) harus bertumbuh secara bersama-sama. Filipi 4:10 "Aku sangat bersukacita dalam Tuhan, bahwa akhirnya pikiranmu dan perasaanmu bertumbuh kembali untuk aku. Memang selalu ada perhatianmu, tetapi tidak ada kesempatan bagimu. Materi khotbah harus disusun dengan mempertimbangkan argumen yang logis, bisa diterima secara nalar, tetapi juga menyentuh perasaan pendengar sehingga khotbah menjadi hidup.

\section{Garis Besar yang Disampaikan Mudah Diingat}

Garis besar khotbah sebaiknya ditulis dengan kata-kata yang sederhana, mudah dimengerti, atau mudah diingat dan dihafalkan oleh seseorang. Garis besar khotbah yang mudah diingat biasanya tidak menggunakan kata-kata (bahasa) yang sulit dimengerti oleh pendengar. Garis besar khotbah yang mudah diingat harus menghindari kata-kata asing atau istilah yang tidak dikenal oleh para pendengarnya. ${ }^{20}$

Jumlah butir atau babak jangan terlalu banyak. Semakin banyak jumlah butir atau garis besar khotbahnya akan semakin sulit untuk diingat. Jumlah butir yang terlalu banyak akan membuat pendengar menjadi bingung atau sulit untuk mengingat secara keseluruhan. Jumlah butir yang terlalu banyak

${ }^{19}$ Hasan Sutanto, Homiletik, Prinsip dan Metode Berkhotbah (Malang: Literatur SAAT, 2007), 171.

${ }^{20} \mathrm{Ibid}, 268$. 
akan membuat si pengkhotbah tidak dapat membahas atau menjelaskan dengan teliti. ${ }^{21}$ Garis besar kotbah supaya mudah dimengerti dan dihafal oleh pendengar sebaiknya berkisar antara 2-5 buah. Lebih dari dari lima butir akan semakin sulit bagi para pendengar untuk bisa mengingatnya dengan baik. Pengkhotbah juga akan semakin sulit untuk mempertahankan perhatian pada pengkhotbah.

Mengapa materi khotbah perlu menggunakan garis besar atau sub gagasan utama? Ibarat sama seperti seseorang mau makan, makanan yang satu piring itu tidak dapat dimakan dalam waktu yang sama, tetapi memerlukan waktu dan tahap-tahap untuk menghabiskan makanan. Khotbah adalah memberi makanan rohani kepada para pendengar dan supaya makanan rohani ini bisa dimakan dengan baik, memerlukan tahaptahap penyampaian dengan dengan tepat.

Garis besar khotbah juga akan membantu pengkhotbah menyusun naskah khotbahnya dengan lebih baik. Membantu pengkotbah untuk mengetahui waktu yang diperlukan untuk berkhotbah. Membuat khotbah nampak lebih teratur, terencana, dan sistematis. Membantu pendengar untuk mengikuti bahkan mengingat khotbah yang disampaikan.

\section{Memainkan Suara Semaksimal Mungkin}

Tuhan telah memberikan sebuah alat yang luar biasa yang dapat digunakan oleh seorang pengkhotbah untuk menyampaikan firman-Nya. Alat yang luar biasa ini adalah suara manusia. Suara adalah nada bunyi yang dihasilkan manusia merupakan instrumen penting bagi seorang pengkhotbah. Kemampuan suara mengungkapkan kedalaman dan makna pesan yang disampaikan oleh seorang pengkhotbah. Menggunakan sarana vokal dengan semaksimal mungkin dalam menyampaikan khotbah akan membantu komunikasi mimbar yang baik.

Semua orang menggunakan suara setiap hari. Namun hanya sebagian orang yang mengetahui mengenai mekanisme suara. Pengabaian semacam demikian mungkin bisa diterima apabila mereka bukan para pembicara profesional. Namun merupakan kesembrononan bagi orang-orang yang

${ }^{21} \mathrm{Ibid}, 269$. 
profesinya menggunakan suara. Para pembicara profesional, seperti seorang pengkhotbah seharusnya mengetahui sifat dan fungsi mekanisme vokal. ${ }^{22}$

Peranan suara dalam komunikasi mimbar bisa memberi pengaruh apakah para pendengar bisa cepat mengerti atau tidak. Volume suara yang terlalu lemah atau kecil bisa menyebabkan para pendengarnya tidak memahami apa yang disampaikan. Setiap kali seorang pengkhotbah mulai berbicara, ia harus bisa mengukur apakah suaranya sudah cukup, perlu dipertahankan, dikurangi dan ditingkatkan.

Setiap orang mempunyai sifat suara yang kas yang tidak sama dengan orang lain, karena itu tidak perlu berusaha untuk meniru suara orang lain. Berusaha untuk meniru suara orang lain, justru menyebabkan pola penyampaian yang kaku dan tidak wajar. Suara yang diperlukan adalah diucapkan dengan jelas dan sesakma, suara bukan dibuat-buat.

Irama suara, harus bervariasi agar lebih enak didengar, lebih mudah dipahami dan tidak membosankan. Irama suara meliputi: kapan harus bicara keras dan kapan harus bicara pelan, kapan dengan kalimat panjang dan kapan dengan kalimat pendek, kapan cepat dan kapan lambat, kapan turun dan kapan naik, kapan harus diam sejenak dan kapan dipenggal, dan sebagainya.

\section{Menggunakan Bahasa Tubuh yang Tepat}

Komunikasi antar manusia bukan hanya mengenal bahasa verbal, tetapi juga dikenal dengan adanya bahasa tubuh atau yang lebih dikenal bahasa nonverbal (tanpa kata-kata). Bahasa nonverbal adalah satu cara penyampaian pesan atau informasi kepada orang lain tanpa menggunakan ucapan atau kata-kata, akan tetapi menggunakan gerakan atau isyarat. Bahasa tubuh adalah proses pertukaran pikiran dan gagasan dengan penyampaian pesan berupa isyarat, ekspresi wajah, gerakan tangan, dengan kontak mata dan lain sebagainya.

Gerakan anggota tubuh dapat membantu pengkhotbah dalam memberi penjelasan dan penggambaran. Gerakan anggota tubuh dapat membantu untuk memberikan penekanan pada ucapan pengkhotbah. Gerakan tubuh dapat menjaga daya tarik dan mempertahankan perhatian pendengar. Sebab

${ }^{22}$ Jerry Vines dan Jim Shaddix, Homiletika, Kuasa dalam Berkhotbah, 381-382. 
sebuah objek yang bergerak lebih memikat untuk dilihat daripada benda yang diam. Gerakan tubuh juga dapat membantu pada pendengar untuk mengalami apa yang yang dirasakan pengkhotbah melalui identifikasi yang mereka lakukan. ${ }^{23}$

Mata, tangan, wajah dan kaki mampu berbicara kepada jemaat sebanyak kata-kata, bahkan melebihi yang diucapkan seorang pengkhotbah. Bahkan menurut pakar ilmu jiwa Albert Mehrabian mengatakan bahwa pengaruh ekspresi wajah memiliki pengaruh terbesar dalam proses komunikasi. Hanya 7 persen pengaruh pesan pembicara melalui kata-kata; 38 persen timbul dari suaranya, dan 55 persen dari ekspresi wajahnya. ${ }^{24}$

Seorang pengkhotbah bukan hanya bisa memanfaatkan komunikasi secara lisan (kata-kata), tetapi juga bisa memanfaatkan bahasa nonverbal. Komunikasi mimbar seorang pengkotbah seharusnya bisa memfaatkan semua sarana komunikasi sehingga transfer gagasan dan ide bisa ditangkap dengan lebih cepat.

Fungsi utama dari penggunaan bahasa nonverbal bisa memperkuat apa disampaikan oleh seorang komunikator dengan menggunakan bahasa lisan. Apabila bahasa lisan yang disampaikan pengkhotbah bisa difahami, maka komunikasi akan menjadi lebih kuat apabila ditambahkan bahasa isyarat, ekspresi wajah, pandangan mata dan gerakan anggota tubuh.

\section{Berkhotbah dengan Tubuh yang Sehat}

Tubuh yang sehat adalah salah satu modal utama dalam setiap kegiatan hidup manusia. Tubuh yang sehat akan membuat kerja lebih maksimal, konsentrasi belajar menjadi lebih baik, penampilan fisik yang menjadi lebih bugar dan masih banyak manfaat lainnya. Demikian juga seorang pengkhotbah salah satu modalnya adalah memiliki tubuh yang sehat. Komunikasi mimbar akan menjadi lebih baik, jika seorang pengkhotbah didukung dengan tubuh yang sehat.

Kegitan apapun tanpa di dukung fisik yang sehat kegiatan tersebut tidak bisa berjalan secara maksimal. Sekalipun kegiatan tersebut masih bisa

${ }^{23}$ Haddon W. Robinson, Cara Berkhotbah yang Baik (Jogyakarta: Andi, 2008), 230-231.

${ }^{24} \mathrm{Ibid}, 223$. 
dilakukan, tetapi hasilnya tidak akan mencapai hasil yang terbaik. Berkhotbah kepada para pendengar membutuhkan dukungan fisik yang prima. Materi khotbah yang berkualitas tidak akan berarti apa-apa jikalau pengkhotbah tidak bisa menyampaikan pesan dengan baik karena faktor tubuh yang sakit. "Dengan tubuh yang siap, pengkhotbah lebih mudah menyampaikan khotbah yang telah disiapkannya"25

Baik dan buruknya kondisi kesehatan jelas mempengaruhi pola penyampaian khotbah menjadi tergangggu. Meski seorang pengkhotbah tidak perlu menjadi seorang atlet amatir untuk memenuhi kebutuhan fisiknya, sebaiknya harus meluangkan waktu untuk mempertahankan kondisi tubuh supaya menjadi prima. Latihan fisik yang sehat akan membuat pengkhotbah lebih mampu berpikir secara jernih dan akan meningkatkan kemampuan kreatif seseorang. ${ }^{26}$

Persiapan khotbah sampai larut malam, justru membuat badan menjadi letih sehingga pada esok hari tubuh menjadi kurang segar, hal yang demikian akan mempengaruhi penyampaian khotbah. Untuk menghindari persiapan khotbah yang sampai larut malam, sebaiknya materi khotbah sudah disiapkan dalam waktu yang cukup. Tubuh yang sehat karena didukung dengan pola hidup sehat, seperti tidur cukup dan pola makan yang sehat. Tubuh yang sehat adalah modal utama untuk segala aktifitas kehidupan, termasuk panggilan untuk berkhotbah.

\section{PENUTUP}

Alkitab sebagai wahyu khusus Allah merupakan sumber primer pertama dan yang paling utama dalam berkhotbah. Alkitab sebagai sumber utama khotbah seharusnya tidak menjadikan seorang pengkhotbah kebingungan dalam mempersiapkan materi khotbah karena di dalamnya terkandung kekayaan yang luar biasa. Seorang pemberita firman adalah menyampaikan warta kebenaran dari Allah. Dalam khotbah seharusnya tidak ada agenda pribadi oleh karena keinginan tertentu dari seorang pengkhotbah.

25Jerry Vines dan Jim Shaddix, Homiletika, Kuasa dalam Berkhotbah, 111.

${ }^{26}$ Ibid, 111-112. 
Sekalipun tidak ada satu bentuk khotbah yang baku, namun bukan berarti sebuah khotbah disampaikan tanpa format atau bentuk yang tidak jelas. Materi khotbah yang sudah dipersiapkan sebaiknya menggunakan desain yang baik. Sekalipun seorang pengkhotbah itu mengkhotbahkan tentang topik atau tema tertentu. Tugas seorang pengkhotbah ketika ia menjelaskan tema tersebut, materi khotbahnya harus di desain dengan baik. Sebab materi khotbah yang disusun dengan menggunakan desain yang baik akan menolong para pendengar untuk memahaminya.

Seorang pengkhotbah adalah seorang komunikator pesan. Seorang komunikator disamping memerlukan pemahaman konteks komunikasi, juga memerlukan pemahaman tentang bentuk-bentuk komunikasi yang harus difahami oleh seorang komunikator. Bila pengertian komunikasi mimbar juga merupakan bagian dari ilmu komunikasi, maka seorang pengkhotbah harus memperhatikan prinsip-prinsip komunikasi.

Jadi seorang pengkhotbah yang baik harus memadukan dua dimensi khotbah secara seimbang, antara materi khotbah yang alkitabiah dan komunikasi mimbar yang baik. Tugas seorang pengkhotbah memperlengkapi diri dengan dua dimensi penting tersebut.

SUNARTO, menyelesaikan program Sarjana Muda Teologi di Sekolah Tinggi Teologi Injili Efrata (STTI Efrata) Sidoarjo, Sarjana Teologi dan Master of Art di Sekolah Tinggi Teologi Injili Abdi Allah (STT IAA) di Pacet Mojokerto. Magister Teologi diperoleh dari Sekolah Tinggi Baptis Indonesia (STBI) di Semarang. Sekarang melayani sebagai dosen dan Pembantu Ketua I di ST'T SAPPI Ciranjang, Cianjur. 